\title{
Career Development Prospects of Women Teachers in the Schools of Samarinda City
}

\author{
Widyatmike Gede Mulawarman \\ Mulawarman University, Samarinda, Indonesia
}

\begin{abstract}
The aim of this research was to describe the obstacles of improving women teachers' career development prospects (internal and external factors) and analyse the goverment regulation in determining the headmaster of elementary school in Samarinda City. The population of this reseach consisted of 150 students selected from 10,036 students by using random sampling. They were 60 students from elementary school, 50 students from junior high school, and 40 students from senior high school. This research was done using the qualitative approach. Data gathering tool used was purposive sampling by snowball method. By using this technique, the researcher expected to obtain adequate key informants. To secure the data validity, triangulation of data sources was applied. The data analysis techniques used were interactive analysis model, which has three components, namely, data reduction, data presentation, and conclusion drawing, and gender analysis model. The research result indicates that the obstacles of improving women teachers' career prospects include internal and external factors. The main internal obstacle of improving women teachers' career prospects in occupying the position of headmaster is the lack of aspiration and motivation of women teachers - They are satisfied with their own condition. They have anxieties that by occupying the position of headmaster, they will have more responsibilities of it. The lower desire to compete with men teachers in occupying the headmaster position and the unwillingness to have mutations are the obstacles of women teachers to occupy the position of headmaster. The main external factor hampering the improvement of women teachers' career prospects in occupying the position of headmaster is the regulation of government in occupying the position of headmaster. It stated that one of the requirements for women teachers to be a headmaster should be a level lower than a headmaster or vice headmaster. Other factors include the lack of opportunities for women teachers to follow trainings and other scientific activities because of lack of socialization.
\end{abstract}

Keywords: career development prospects, women teachers, the school

\section{Introduction}

Education is one of the important means to increase human resources. Education is the right of each citizen. The objectives of education are to make people become intelligent; to develop their minds, piety to the God, politeness behaviours, and skills and knowledge; and to turn them into mentally healthy and physically healthy persons. These matters can be achieved if all elements are functioning well, they are students, teachers, and all equipment.

Teacher, as the main actor of the educational process, is one of the professions that is directly related to education and is one of the jobs needed by most women.

Widyatmike Gede Mulawarman, lecturer, Faculty of Teacher Training and Education, Mulawarman University. 
Samarinda, as the capital city of East Kalimantan, consists of 219 elementary schools, 73 junior high schools, 34 senior high schools, and 40 vocational schools. They are spreaded in six subdistricts (These schools have 5,814 women teachers $(57.93 \%)$ and 4,222 men teachers (43.01\%)).

The 10,036 teachers in Samarinda who occupy the position of headmaster are 273 males and only 26 female teachers. Of course, the screening to be a headmaster is strict, so there is a big gap in the number of men and women teachers. There are so many factors hindering it. Exactly, the number of women teachers is more than men teachers, and it is a productive potential to occupy the highest position in the school.

Fitzgerakj and Crites (1980) stated that there were no fundamental factors between improving men's careers and women's careers, but it is to be more complex because of the lack of socialization for women. They also stated that the career aspiration of women was lower than their own potential because they focus on the gender stereotype career (Brown \& Brooks, 1987).

Paying attention to the gap of men and women teachers, it is necessary to conduct research on the factors hindering women teachers' career prospects to occupy the position of headmaster. The other factors may be from themselves or others.

This research has been done in Samarinda. It was done there because Samarinda, as the capital city of East Kalimantan, is the center of education and there are so many women teachers in all levels of education. The teachers are spread in government or non-government schools. From the explanation, it is necessary to do deeper research to describe some obstructive factors for women teachers to occupy the position of headmaster.

\section{Research Questions}

This research is guided by the following four research questions:

1. What are the obstructive factors for improving women teachers' career prospects in Samarinda City?

2. What are the internal obstructive factors for improving women teachers' career prospects in Samarinda City?

3. What are the external obstructive factors for improving women teachers' career prospects in Samarinda City?

4. Does government regulation about the appoinment of headmaster hinder the improvement of women teachers' career prospects in Samarinda City?

\section{Research Purposes}

The purposes of this research are:

(a) To describe the factors hindering the improvement of women teachers' career prospects in Samarinda City;

(b) To describe the internal factors hindering the improvement of women teachers' career prospects in Samarinda City;

(c) To describe the external factors hindering the improvement of women teachers' career prospects in Samarinda City;

(d) To analyse the regulation of government on the oppoinment of headmaster on the improvement of women teachers' career prospects in Samarinda City.

\section{Research Effects}

The effects of the research are: 
(a) To give input data for regional government in determining the policy of the system of improving teacher career to get a justice and equal gender;

(b) To give input data for teachers, especially for women teachers who have the potential to occupy the position of headmaster so that they do not hesitate to accept the job;

(c) To give input data for other researchers to enlarge their knowlegde to do deeper research in relation to primary education.

\section{Methodology}

This research was done in Samarinda City for three months. It was running from August to December 2013. The data of the study consist of primary and secondary data. Primary data are the places and events related to the existence of teachers in schools gathered from observation, interviews, and focus group discussion for eliciting teachers' experience in pursuing career in school. Secondary data are related to statistical data on the number of teachers separated by male and female, data of ranking, data of working period, data of teacher education, and results of related studies formerly conducted.

The data gathering technique used in this study was purposive sampling by snowball method. By using this technique, the researcher expected to get adequate key informants. To secure the data validity, triangulation of data sources was applied.

The data analysis technique used was interactive analysis model, which has three components, namely, data reduction, data presentation, and conclusion drawing (Miles \& Huberman, 1985). Data reduction is a process of selecting, focusing, simplifying, and abstracting of rough data found in the field record. The field data are in the forms of results of interviews, summary of focus group discussion, or secondary data transcribed in the form of report, then reduced to select significant aspects.

The focus of this study is to answer the problems as follows:

(a) Factors hindering women teachers' career prospects (analyses of documents/government regulations on the requirements or criteria in pursuing career in the position of principal);

(b) Internal factors causing differences in the opportunity between women teachers and men teachers in pursuing career in the position of headmaster;

(c) External factors causing differences in the opportunity between women teachers and men teachers in pursuing career in the position of headmaster.

Regarding the above requirements, data were screened by the main respondents/key informants, namely, teachers who have reached the position of headmaster or vice headmaster and have held a strategic position in school and teachers who have not become the headmaster but have met the requirements for promotion to hold a strategic position in school. In providing these data, some techniques were used:

(a) Detailed interviews (interview guideline) and observations, which were used for screening cases related to teacher's career inhibited by the prevailing regulations;

(b) Questionnaire, which was related to the condition of the teacher concerned;

(c) Focus group discussion - after selection and sorting of the data, essential data are then discussed to be used as the materials for analysis.

Data presentation is an assembled information organization enabling conclusion of the study. In this case, the data presented cover various kinds of matrixes, drawings or schemes, networks, related activities, and tables. Conclusion drawing is organizing the data gathered so that conclusion can be drawn. 
Besides interactive analysis, the researcher also used gender analysis model of Sara H. Longwee's "Female Empowerment Framework", which was used to analyze the significance of development for females (Relawati, 2011, p. 119). Female empowerment covers three aspects: (a) capacity building, namely, building of female capacity; (b) cultural change, namely, cultural change favoring females; and (c) structural adjustment, namely, structural adjustment favoring females. Empowerment efforts are focused on achievement of people's welfare by gender equality. There are five criteria of analysis applied in this method, namely, (a) welfare; (b) access; (c) awareness; (d) participation; and (e) control.

\section{Discussion}

There are two factors that influence the improvement of women teachers' career.

\section{Internal Factors}

Internal factors that influence the improvement of women teachers' career include the purpose of women working, the support of husbands, and the support of their children.

The purpose of the women working. Women working outdoor have double roles, which are doing housework and public work. They have high responsibilities. It will make them diffcult to improve their career only if they have positive attitudes (supported by family), which are self-actualization (23.33\%), increasing insight $(51.33 \%)$, and fulfilling the family need $(25.33 \%)$. These matters are not hindering women's career but are motivation to improve their career as a teacher.

The support of husbands. Concerning the support of husbands, it is a main internal factor influencing the improvement of women teachers' career. Support from husbands is categorized as follows.

Most of the husbands "Very supported" their wives' work (60\%) and 38\% of them are "Supportive". These supports are a proof or major capital for women teachers to improve their career. But these facts are not used fully by women teachers. It is supported by the data from 150 respondents that there is only one person as the headmaster, and four persons as the vice headmaster. It is an ironic condition because they are supported by their husband. In other words, women teachers have not been motivated yet to occupy the position of headmaster.

Child support. The relation of mothers working outdoor and their children is very good. The result of this research indicated that most of children support their mothers to work outdoor. The children support has an important role to work outdoor, so it will increase the quality of their work. This condition occurred for most of women teachers in Samarinda. Most of them get support from their children.

In doing daily activities, a teacher is not enough just to work in the classroom only. To improve the ability, sometimes, teachers have opportunities to improve their ability to form a variety of activities. Sometimes, women teachers got on offer to follow training, upgrading, study, etc., and this program runs in outside of this city. Some women techers are proud of joining it because it is rarely to be offered to them, and some of them feel difficult to follow it because it is not supported by their children who are often left out of town.

Most children are proud of having their mothers as teachers. They do most of the work at home to help their mother's work. Moreover, children are also ready to finish other homework.

Internal personal factors. The internal personal factors supporting women teachers to do their assignment and to improve their career are their proud of having the profession of teacher. Women teachers are also interested in their profession, and they are happy to teach everyday. They also have high will in increasing 
their knowledge by studying in higher level if they are given a chance to follow this program.

To achieve the career as a teacher, it can be seen from its position in the structural position, as the headmaster or vice headmaster and other functional position that has relation to increasing degree (please check the sentences marked in red). In this case, government makes a regulation as a rule to increase its degree and the requirement to be a headmaster or vice headmaster.

\section{External Factors}

Government regulation. The regulations on the teacher career in the Decree No. 085/U/1994 of the Minister of Education and Culture of the Republic of Indonesia stipulated on the appointment and dismissal of principals. Not all the respondents know this regulation, so although they have specified requirements to get this opportunity, they do not know their right to be a candidate.

Based on the respondents' level of education, stratification, and the working experience, they fulfill the requirement of the regulation of National Education Minister as a candidate of headmaster, but unfortunately, the number that sits as the headmaster or vice headmaster is still very minimal.

For functional occupation, it is stated in the Decree No. 0433/P/1993 and No. 25/1993 of the National Education Minister and Corporation of State Administration on the guidance of the application of teacher functional occupation and its rules. Most of the respondents have just known this regulation when they want to grade their credit point for promoting their degree and functional occupation.

Although the number of women teachers working for structural occupation is still less, but they are able to achieve a higher degree in working for functional occupation. Fourty-nine percent of the respondents occupy functional occupation of "adult teacher" (on a IV degree). It describes that women teachers are able to get their career on functional occupation well.

Teachers' functional career is determined by themselves based on their seriousness, abilities, and skills in implementing the learning process without any tough competition with men. It describes that if women teachers compete with men teachers, women teachers have less opportunity than men teachers.

A lot of the respondents that are able to occupy the functional "young teacher", "teacher", and "adult teacher" described that the government's regulation on the functional occupation is known and recognized by them and it is not the obstacle to achieve a higher level of teacher career.

Community response. The society's opinion of women working outdoor is not positive at all. Some people think that it is better for women not to work. The society's positive thought will give support to them, such as does not require working women to carry out the tasks of the community and a positive response even as members of society cannot be fully active in social life.

The public generally agree to women teachers because they think that it is a holly work and it is not full-time as other jobs. The idea for women as teachers give a wide chance to get support for them. Furthermore, they will be working in so many kinds of institutions or organizations of the society. The purpose of working here is for social working, to strangle women's need, and to increase women's human resources.

Beside working, the respondents are also members of social organization in many levels as a form of self-existence and public recognition of the skills, knowledge, insight, and the desire that always exist in being a teacher.

The height of women's ability is not only proved from their career as teachers, but also their ability in so many social organizations. Most of the respondents are members of social and community organizations. Some 
of them are in the environment place and others are in the higher level, such as in the city or in the province.

Working environment. The other external factors that influence the improvement of women teachers' career prospects are from where they work and teach. Working environment consists of male workers or female workers, where career competition never takes place.

The working environment of the respondents generally does not differentiate between women and men teachers, because they have done their work as instructed in their subjects. Teachers working together does not differentiate gender, but help each other.

Support provided in the form of co-operation in carrying out duties or as a substitute teacher who is absent when there is more based on shared fields / subjects of teaching regardless of gender. Therefore, absence of one of them is not a barrier along the already coordinated with the same teacher. In this case, the absence of some teachers will not cause problems in teaching, as long as they coordinate it.

The objectivity in scoring during the learning and teaching process is described by neglecting the gender, whether from teachers or headmasters. It will make the situation condusive and it will be a motivation for women teachers in improving their career. It has also proved that there are no obstacles in improving their career and their functional occupation.

\section{Conclusion}

Based on the research result, the elements influencing the improvement of women teachers' career prospects include internal factors and external factors.

Internal factors hindering the improvement of women teachers' career prospects to occupy the position of headmaster are:

1. Women teachers have low aspiration and innovation, so that they are easy to be satisfied, and some teachers are anxious that occupying the position of headmaster will also add responsibility;

2. Women teachers have low need to compete with men teachers to occupy the position of headmaster;

3. Women teachers not following mutation in promotion is also an obstacle for them to achieve the structural occupation career, specially for headmaster.

External factors hindering the improvement of women teachers' career prospects to occupy the position of headmaster are:

1. The regulation of government in appointing the position of headmaster. It stated that to occupy the position of headmaster candidate, teachers should be hold a level lower than headmaster or vice headmaster;

2. Women teachers lack of opportunity to join trainings and other scientific discussions because of lack of socialization.

\section{Recommendations}

Women teachers in Samarinda generally have got support from their husbands and children to improve their career, but they have not used it optionally. They should be able to apply it as well as possible in the city or outside the city, to follow upgrading, training, studying, or the other offer in order to improve their career.

Regulations on the terms of appointment of the head of school and work environment do not distinguish between male and female teachers, but in fact, there are only few women teachers occupying the structural job as a headmaster. It is caused by the internal factors from themselves. It is suggested that women teachers should 
try to increase their motivation by following training of leadership, increasing their self-esteem in order to get the structural job, and improving their abilities to achieve the functional occupation.

Social environment and working environment in the form of good cooperation between teachers and headmasters do not distinguish between men teachers and women teachers. Those (who?) strongly support the advancement of women, but in general, women teachers do not take advantage of the support. Women teachers should be able to take advantage of these opportunities and how to exchange ideas among some members of the community and teachers and headmasters in order to identify the weaknesses and advantages possessed by themselves. In other words, women teachers are expected the chance by discussing it with the society, teachers, and headmasters.

\section{References}

Ahmed, L. (2000). Female and gender. Jakarta: Lentera Publisher.

Anonymous. (1994). Direction for implementation of national education system 1993-1994. Jakarta: Ekojaya Publisher.

Brown, D., \& Brooks, L. (1987). Career choice and development. San Francisco, C.A.: Jossey-Bass Publishers.

Fagih, M. (1996). Gender: A means of social analysis. In Analysis of gender in understanding female issues. Bandung: Akatiga Foundation.

Fagih, M. (1997a). Gender awareness: Guidelines for employees. Jakarta: ILO Indonesia.

Fagih, M. (1997b). Analysis of gender and social transformation. Yogyakarta: Pustaka Pelajar.

Goldenberg, H., \& Goldenberg, I. (1985). Family therapy: An overview. Monterey: California Books/Cole Publishing Company.

Hadjar, I. (1996). Principles of quantitative research methodology in education. Jakarta: PT Raja Grafindo Persada.

Mosse, J. C. (1996). Gender and development. Yogyakarta: Pustaka Pelajar.

Muhadjir, N. (2000). Qualitative research methodology. Yogyakarta: Rake Sarasin Publisher.

Miles, M. B., \& Huberman, A. M. (1985). Qualitative data analysis. Thousand Oaks, C.A.: Sage Publications.

Notosusanto, S., \& Purwandari, E. K. (Eds.). (1997). Females and empowerment. Jakarta: Study Program of PPS of Indonesia University.

Relawati, R. (2011). Konsep dan aplikasi penelitian gender (in English). Bandung: Muara Indah.

Soewondo, N. (1984). Position of Indonesian women. Jakarta: Balai Aksara.

Subhan, Z. (2002). Reconstruction of understanding of gender in Islam. Jakarta: El Kahfi.

Syaukani, H. R. (1999). Society empowerment. Samarinda: Development Study Institution.

Wijaya, H. R. (1996). Research in gender perspective. In Analysis of gender in understanding females issues. Bandung: Akatiga Foundation. 